\title{
Ecomorphology of crabs and swimming crabs (Crustacea Decapoda Brachyura) from coastal ecosystems
}

\author{
Murilo Zanetti Marochi*, Setuko Masunari
}

Universidade Federal do Paraná

(Av. Coronel Francisco Heráclito dos Santos, 210, Post box 19020 CEP: 81531-980, Curitiba, Paraná, Brazil)

*Corresponding author: murilo.marochi@gmail.com

\begin{abstract}
Brachyuran crabs are one of the most diverse taxa of crustaceans, occurring in almost all coastal habitats. Due to their high morphological diversification, the authors sought to ascertain the existence of morphological patterns related to the habitat of coastal brachyuran crabs. We analyzed 17 species from mangrove forests, rocky shores, sandy beaches and exclusively aquatic marine/estuarine ecosystems. A total of 16 linear measurements of males and 17 of females were obtained for each habitat. We were able to discriminate three functional groups of crab species, based on their habitat: 1. Complex Substrates, 2. Semiterrestrial, 3. Exclusively Aquatic. The species belonging to the Complex Substrates group had long ambulatory legs, as well as being heteroquely related to uneven terrain. Semiterrestrial species showed ambulatory legs of different sizes, allowing them to walk easily on the terrestrial terrain due to the long fourth ambulatory leg, and long eyestalks which are important for visual communication. Exclusively Aquatic species showed the largest carapace widths and the shortest eyestalks. The presence of different crab lineages in the environments analyzed allows us to demonstrate the clear evolutionary convergence, by which the crabs adapted to their specific habitat and environment.
\end{abstract}

Descriptors: Brachyura community, Ecomorphological attributes, Morphometry, Morphological adaptation.

\section{RESUmo}

Caranguejos braquiúros são um dos grupos mais diversificados de crustáceos, ocorrendo na maioria dos habitats costeiros. Devido à alta diversificação morfológica, procurou-se verificar a existência de padrões morfológicos relacionados ao habitat desses animais. Foram analisadas 17 espécies provenientes de manguezal, costão rochoso, praia de areia e ecossistema exclusivamente aquático marinho/estuarino. Em cada ambiente um total de 16 medidas lineares foi obtido para machos e 17 de fêmeas. Foram discriminados três grupos funcionais de espécies de caranguejos, baseado em seu habitat: 1. Substratos complexos, 2. Semiterrestre, 3. Exclusivamente aquático. As espécies pertencentes ao grupo Substratos complexos apresentaram pernas ambulatórias longas, bem como heteroquelia relacionada à vida em substratos irregulares. Espécies do grupo Semiterrestre apresentaram pernas ambulatórias de tamanhos distintos, o que lhes permite caminhar de maneira ágil sobre o ambiente terrestre graças à quarta perna ambulatória maior e aos pedúnculos oculares longos, importantes para a comunicação visual. Espécies do grupo Exclusivamente aquático apresentaram as maiores larguras de carapaça e pedúnculos oculares curtos. A presença de distintas linhagens de caranguejos nos ambientes analisados permitiu demonstrar uma clara convergência evolutiva, adaptando os caranguejos ao seu habitat e ambiente específico.

Descritores: Comunidade de Brachyura, Atributos ecomorfológicos, Morfometria, Adaptação morfológica. 


\section{INTRODUCTION}

The relationship between morphology and the environment has been an area of study since the dawn of modern biology, and before (DARWIN, 1859). Darwin began the modern study of ecomorphology using the explanatory power of adaptation via natural selection, providing an evolutionary approach to ecomorphological analysis. VAN DER KLAAUW (1948) used the term morphological ecology to define the relationship between an organism's structures and its environment. However, the term ecomorphology was only introduced by KARR and JAMES (1975).

Ecomorphology is based on the idea that the body shape of an organism and its lifestyle are correlated, and the environment acts on the phenotype, selecting for appropriate traits within the constraints of development and phylogeny (GATZ, 1979; KEAST, 1985; NORTON et al., 1995; LABROPOULOU; ELEFTHERIOU, 1997; PIORSKI et al., 2005). These correlations can be evaluated through the use of multivariate techniques that allow the analysis of large numbers of morphometric characters (WINEMILLER, 1991). There are several publications concerning the ecomorphology of different taxonomic groups (KESLER; BAILEY, 1993; BETZ, 1998; HARISSON; CRESPI, 1999; CARVALHO; ARAUJO, 2007; TRONTELJ et al., 2012).

The brachyuran crabs and swimming crabs currently comprise more than 7,000 species, and show a high morphological complexity due to the "carcinification" process, in which the head and thoracic somites are fused, and the first chelate pereipods and walking legs are situated on the side of the body (DE GRAVE et al., 2009). They are considered the most diverse group of crustaceans, present in almost all coastal habitats including mangrove forests, rocky shores, sandy beaches and other benthic habitats from all zoogeographical regions (except Antarctica) down to 6,000 meters below sea level in abyssal ocean depths, and up to 2,000 meters above sea level in terrestrial environments (NG et al., 2008; DE GRAVE et al., 2009).

Each ecosystem has unique physicochemical characteristics that require that the fauna acquires a number of morphological, physiological and behavioral adaptations by different evolutionary processes. In ecomorphological studies conducted in coastal environments, segregation of species or groups of species by habitat use is well documented in vertebrates (STREELMAN et al., 2002; GOMES et al., 2003; RIBAS et al., 2004; CARVALHO; ARAUJO, 2007; PIORSKI et al., 2007).
Based on the premise that the morphology of an animal living in a certain area must approach an optimum form in order to ensure the best performance in this habitat (IRSCHICK et al., 1997), and in the light of the high morphological complexity of this group, the objective of this study was to evaluate the ecomorphology of Brachyuran crabs based on the linear measurements of their bodily dimensions.

\section{MATERIAL AND METHODS}

Brachyuran decapods were sampled manually or with the aid of "double-rig" trawls in the coastal ecosystems of southern Brazil (from $25^{\circ} 01^{\prime} \mathrm{S}-48^{\circ} 12^{\prime} \mathrm{W}$ to $26^{\circ} 46^{\prime} \mathrm{S}-48^{\circ} 38^{\prime} \mathrm{W}$ ) located in the municipalities of Guaratuba, Matinhos and Pontal do Paraná in Paraná State (PR) and in the municipalities of Itapoá and Penha in Santa Catarina State (SC). These collection sites are located on a coastal plain composed of sand, muddy areas, mangrove forests and saltmarshes, all with a similar humid subtropical climate (Cfa) (VANHONI; MENDONÇA, 2008).

The specimens were collected in the following biotopes and ecosystems: infralittoral benthopelagial (Pontal do Paraná), sandy beaches (Itapoá), rocky shores (Farol Island, Matinhos), mangrove forests (Guaratuba and Itapoá), lantern nets of marine oyster farms (Guaratuba) and lantern nets of marine scallop farms (Penha), from December 2009 to January 2011. Decapods living on rocky shores, in mangrove forests, and on sandy beaches and bivalve marine farms were captured manually, while the exclusively aquatic fauna was obtained with trawls of the "double-rig" type. In the laboratory, the individuals were preserved in $75 \%$ ethanol and identified based on MELO (1996). Only adult crabs of both sexes were analyzed and individuals with appendages undergoing regeneration were excluded from the study.

The following seven species deposited in the Museum of Natural History of Capão da Imbuia (MHNCI) in Curitiba, PR, were also included in the present study: Armases angustipes from a mangrove area $(\mathrm{n}=13)$, Eriphia gonagra from rocky shores $(\mathrm{n}=8)$, Menippe nodifrons from rocky shores $(\mathrm{n}=2)$, Pilumnus dasypodus from a rocky shore $(\mathrm{n}=1)$, Sesarma rectum from a mangrove area $(\mathrm{n}=6), \mathrm{Uca}$ (Minuca) thayeri from a mangrove area $(\mathrm{n}=1)$ and $U c a$ (Uca) maracoani from mangrove areas $(\mathrm{n}=29)$.

Males and females were analyzed separately in view of their sexual dimorphism. At least 5 males and 5 females of each species, combining data from collected individuals 
and those from museum collections, were analyzed. We took 16 linear measurements for males, and 17 for females (Table 1) using a digital calliper (accuracy $0.05 \mathrm{~mm}$ ) (Figure 1): carapace width $(\mathrm{CW})$, carapace length $(\mathrm{CL})$, carapace height $(\mathrm{CH})$, width of the $4^{\text {th }}$ abdominal somite of the female abdomen (LAF), width of the orbital region (OW), total length of ambulatory leg 1 (TLA1), length of the merus of ambulatory leg 1 (LM1), width of the merus of ambulatory leg 1 (WM1), length of the dactyl of ambulatory leg 1 (LD1), total length of ambulatory leg 4 (TLA4), length of the merus of ambulatory leg 4 (LM4), width of the merus of ambulatory leg 4 (WM4), length of the dactyl of ambulatory leg 4 (LD4), length and height of the major cheliped propodus (LMC and HMC) and length and height of the minor cheliped propodus ( $\mathrm{LmC}$ and $\mathrm{HmC}$ ).

In order to take the influence of the size of the species on the data into account, all the bodily dimensions were treated as proportional to $\mathrm{CW}$ in the Principal Component Analysis (PCA), Cluster Analysis and permutation-based multivariate analysis of variance (PERMANOVA). CW was chosen as the reference dimension as it is considered by several authors to be less sensitive to distortion between size classes (ORENSANZ; GALLUCI, 1988; HINES, 1991; HARRISON; CRESPI, 1999). Thus, a total of 15 measures proportional to $\mathrm{CW}$ for males and 16 for females were acquired.

Measurements were ordinated using Principal Components Analysis (PCA, using the covariance matrix) (PIELOU, 1984). To test the influence of environment, taxonomic level (family) and sex on the morphological data a permutation-based multivariate analysis of variance (PERMANOVA) was performed. To visualize the relationship between the populations, a UPGMA cluster analysis was carried out, using the Euclidean distances of the mean of the measurements. The cophenetic correlation coefficient was used to verify the adjustment between the dissimilarity matrix and the dendogram (SOKAL; ROHLF, 1962).

All data were tested for normality and homoscedasticity, and statistical analyses were performed using a/the vegan package (OKSANEN et al., 2012) in the R environment (R Development Core Team 2011, available at: www.R-project.org).

\section{RESULTS}

Measurements of 193 females and 199 males of the following 17 brachyuran species were taken (Table 1):
Acantholobulus schmitti (RATHBUN, 1930), Aratus pisonii (H. MILNE EDWARDS, 1873), Armases angustipes (DANA, 1852), Callinectes danae Smith, 1869, Eriphia gonagra (FABRICIUS, 1781), Eurypanopeus dissimilis (BENEDICT; RATHBUN, 1891), Goniopsis cruentata (LATREILLE, 1803), Hepatus pudibundus (HERBST, 1785), Libinia ferreirae Brito CAPELLO, 1871, Menippe nodifrons STIMPSON, 1859, Ocypode quadrata (FABRICIUS, 1787), Pachygrapsus transversus (GIBBES, 1850), Panopeus austrobesus WILliAMS, 1983, Pilumnus dasypodus KINGSLEY, 1879, Sesarma rectum RANDALL, 1840, Uca (Uca) maracoani (LATREILLE, 1802) and Uca (Minuca) thayeri RATHBUN, 1900.

For males, the first two axes produced by principal component analysis (PCA) accounted for $84.14 \%$ of the variation. The dimensions that most influenced the distribution of species on axis 1 were length of the merus of ambulatory leg 4 and total length of ambulatory leg 4 that accounted for $57.32 \%$ of the variation, while on axis 2 , that accounted for $26.82 \%$ of the variation, were LMC and $\mathrm{HmC} / \mathrm{CL}$ (Table 2).

For females, the first two axes of the PCA accounted for $79.89 \%$ of the variation. Axis 1 accounted for $65.48 \%$ of the variation, and the dimensions that most influenced it were TLA4 and LM1, whereas on axis 2, accounting for $14.41 \%$ of the variation, it was mostly influenced by HMC and LMC (Table 2).

By means of the PCA, it was possible to distinguish three groups of crab species in terms of their lifestyle or the type of habitat in which they occur (Figure 2): 1. Complex Substrates, 2. Semiterrestrial and 3. Exclusively Aquatic.

The Complex Substrates group was composed of the following crab species of the families Eriphidae, Grapsidae, Menippidae, Panopeidae and Pilumnidae: $A$. schmitti, E. gonagra, E. dissimilis, M. nodifrons, $P$. transversus, $P$. austrobesus and $P$. dasypodus. These species live on rocky surfaces and in their crevices, on fallen logs, or on oyster beds, and were characterized by the presence of similar TLA1 and TLA4 (difference not exceeding 17\% between these two dimensions), robust major cheliped propodus (HMC $\geq 35 \%$ of LMC) and marked heterochely.

The Semiterrestrial group was composed of species of the families Grapsidae, Sesarmidae and Ocypodidae: A. pisonii, A. angustipes, G. cruentata, O. quadrata, $S$. rectum, $U$. maracoani and $U$. thayeri. This group is characterized by contrasting values between TLA1 
Table 1. List of brachyuran crab species, number of individuals analyzed and ecosystems or biotopes in which they were recorded.

\begin{tabular}{|c|c|c|c|}
\hline Species & $\mathrm{N}$ & Ecosystem (Biotope) & References \\
\hline Acantholobulus schmitti & 37 & $\begin{array}{l}\text { Rocky shores and oyster lanterns (rocky, sandy, muddy } \\
\text { and biodetritic bottoms) }\end{array}$ & $\begin{array}{l}\text { MELO (1996), MAROCHI and } \\
\text { MASUNARI (2011), present study }\end{array}$ \\
\hline Aratus pisonii & 12 & $\begin{array}{l}\text { Mangrove forests/swamps (trunks, branches an aerial } \\
\text { roots on mangrove trees, surface of rocks, fallen logs and } \\
\text { mud) }\end{array}$ & MELO (1996), present study \\
\hline Armases angustipes & 17 & Mangroves (over bromeliads and marginal rocky areas) & MELO (1996), present study \\
\hline Callinectes danae & 26 & $\begin{array}{l}\text { Estuary and benthopelagic open sea (sandy and muddy } \\
\text { bottoms) }\end{array}$ & MELO (1996), present study \\
\hline Eriphia gonagra & 15 & $\begin{array}{l}\text { Rocky shores and banks of the colonial polychaete } \\
\text { Phragmatopoma caudata (Kröyer, 1856), corals, algae } \\
\text { and sponges }\end{array}$ & $\begin{array}{l}\text { MELO 1996, MAROCHI and } \\
\text { MASUNARI (2011), present study }\end{array}$ \\
\hline Eurypanopeus dissimilis & 19 & Rocky shores and oyster lanterns & $\begin{array}{l}\text { MAROCHI and MASUNARI (2011), } \\
\text { present study }\end{array}$ \\
\hline Libinia ferreirae & 26 & Open sea (infralittoral of sandy and muddy bottoms) & MELO (1996), present study \\
\hline Goniopsis cruentata & 10 & $\begin{array}{l}\text { Mangroves (surface of muddy soil, trunks and aerial roots, } \\
\text { and hollows of fallen logs) }\end{array}$ & MELO (1996), present study \\
\hline Hepatus pudibundus & 58 & $\begin{array}{l}\text { Open sea (infralittoral muddy, sandy and biodetritical } \\
\text { bottoms) }\end{array}$ & MELO (1996), present study \\
\hline Menippe nodifrons & 19 & $\begin{array}{l}\text { Rocky shores, banks of } P \text {. caudata and oyster lanterns } \\
\text { (tidal pools, rock crevices) }\end{array}$ & $\begin{array}{l}\text { MELO (1996), MAROCHI and } \\
\text { MASUNARI (2011), present study }\end{array}$ \\
\hline Ocypode quadrata & 19 & Sandy beaches (supralittoral of dune and sandbank areas) & MELO (1996), present study \\
\hline Pachygrapsus transversus & 39 & $\begin{array}{l}\text { Rocky shores, mangroves, banks of } P \text {. caudata (surface } \\
\text { and crevices of rocks) }\end{array}$ & MELO (1996), present study \\
\hline Panopeus austrobesus & 34 & $\begin{array}{l}\text { Mangroves, rocky shore and lanterns oysters (hollows of } \\
\text { fallen logs, crevices of rocks) }\end{array}$ & MELO (1996), present study \\
\hline Pilumnus dasypodus & 18 & $\begin{array}{l}\text { Phytal, rocky shores, mangroves and oyster lanterns (san- } \\
\text { dy and biodetritical bottoms) }\end{array}$ & $\begin{array}{l}\text { MASUNARI (1982), MELO (1996), } \\
\text { MAROCHI and MASUNARI (2011), } \\
\text { present study }\end{array}$ \\
\hline Sesarma rectum & 10 & Mangroves (sandy and muddy substrates) & MELO (1996), present study \\
\hline Uca maracoani & 27 & $\begin{array}{l}\text { Mangroves (burrow dweller in muddy tidalflats without } \\
\text { vegetation) }\end{array}$ & $\begin{array}{l}\text { CRANE (1975), MELO (1996), } \\
\text { MASUNARI (2006) }\end{array}$ \\
\hline Uca thayeri & 15 & $\begin{array}{l}\text { Mangroves (burrow dweller in muddy soil among } \\
\text { mangrove trees) }\end{array}$ & $\begin{array}{l}\text { CRANE (1975), MELO (1996), } \\
\text { MASUNARI (2006), present study }\end{array}$ \\
\hline
\end{tabular}

and TLA4, the first being larger than the latter in most species- A. pisonii, O. quadrata, U. maracoani and $U$. thayeri - robust major cheliped propodus (HMC $>35 \%$ of LMC) which strongly contrasts with the minor propodus in four species: O. quadrata, S. rectum, U. maracoani and $U$. thayeri. Furthermore, O. quadrata, S. rectum, $U$. maracoani and $U$. thayeri dig burrows in unconsolidated substrata of mangrove areas and sandy beaches, and walk mostly on the soil surface. On the other hand, A. pisonii, A. angustipes and G. cruentata live mostly on the surface of trunks and shelter temporarily in their hollows.

The Exclusively Aquatic group was composed of C. danae, H. pudibundus and L. ferreirae. They were characterized by contrasting TLA1 and TLA4, the former being larger than the latter, with weak heterochely and no robust cheliped propodus (HMC less than $35 \%$ of LMC), with the exception of $H$. pudibundus.

The range of $\mathrm{CW}$ of the brachyuran crabs varied widely, but there was a predominance of larger crabs in the Exclusively Aquatic group (Figure 3).

The cluster analysis (Figure 4) showed similar results to those observed in the PCA. The males of genus $U c a$ were isolated from other semiterrestrial species, due to the influence of the major chelipeds (about four times bigger than the minor ones, in the species analyzed) that are outliers relative to smaller chelipeds. The remaining species of the semiterrestrial male group, composed of $A$. pisonii, 

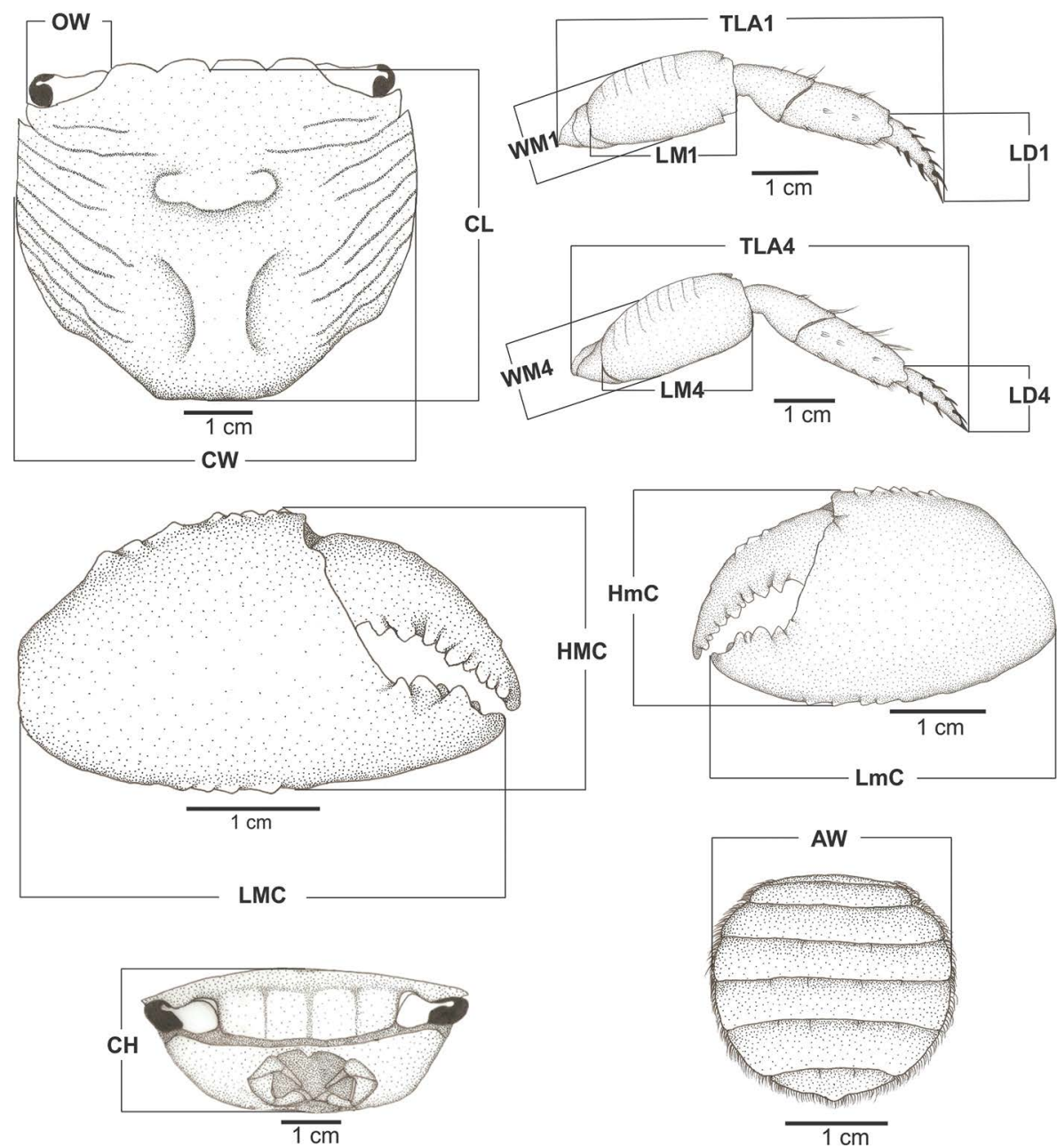

Figure 1. Schematic figures with indication of morphometric measurements. AW: width of the $4^{\text {th }}$ abdominal somite of females abdomen, $\mathrm{CH}$ : carapace height, CL: carapace length, CW: carapace width, HMC: height of the major cheliped propodus, HmC: height of the minor cheliped propodus, LD1: length of the dactyl of ambulatory leg 1, LD4: length of the dactyl of ambulatory leg 4, LMC: length of the major cheliped propodus; LmC: length of the minor cheliped propodus, LM1: length of the merus of ambulatory leg 1, LM4: length of the merus of ambulatory leg 4, OW: width of the orbital region, TLA1: total length of ambulatory leg 1, TLA4: total length of ambulatory leg 4, WM1: width of the merus of ambulatory leg 1, WM4: width of the merus of ambulatory leg 4 .

G. cruentata, S. rectum, A. angustipes, and O. quadrata, belong to the same group visualized in PCA, as did the Complex Substrates group with the exception of $E$. dissimilis. The species of the Exclusively Aquatic group $C$. danae, L. ferreirae and H. pudibundus did not formed a single branch.

For females, the similarity between the two analyses was observed for the species group $A$. pisonii, G. cruentata, S. rectum, A. angustipes, O. quadrata, U. maracoani and $U$. thayeri, and for the group A. schmitti, E. dissimilis, E. gonagra, $M$. nodifrons, $P$. transversus, $P$. austrobesus and $P$. dasypodus. In the Exclusively Aquatic group $C$. danae and $H$. pudibundus formed a single branch and $L$. ferreirae a sister group of Complex Substrates.
For the grouping analysis of linear measurements, high respective cophenetic correlation values of males ( $R=0.81)$ and females $(R=0.75)$ were obtained, indicating that the groupings satisfactorily reflect the structure of the morphometric data.

PERMANOVA revealed a significant influence of habitat type (3 proposed groups), sex and taxonomic level (family) $(p<0.001)$ in the morphometric data (Table 3$)$.

\section{DISCUSSION}

Recent ecomorphological studies have demonstrated the existence of consistent relationships between the morphology and the habitats occupied by 
Table 2. Factor loadings obtained in PCA for the first two axes and the explanation of the variance of the body dimensions of males and females of the brachyuran crab species analyzed.

\begin{tabular}{|c|c|c|c|c|c|}
\hline Male dimensions & PCI & PCII & Female dimensions & PCI & PCII \\
\hline & & & AW & -0.80 & -0.20 \\
\hline $\mathrm{CH}$ & -0.83 & -0.01 & $\mathrm{CH}$ & -0.77 & -0.16 \\
\hline $\mathrm{CL}$ & -0.60 & 0.62 & $\mathrm{CL}$ & -0.71 & -0.33 \\
\hline HMC & -0.68 & -0.47 & HMC & -0.07 & 0.93 \\
\hline $\mathrm{HmC}$ & -0.14 & 0.62 & $\mathrm{HmC}$ & -0.22 & 0.85 \\
\hline LD1 & -0.48 & 0.29 & LD1 & -0.56 & 0.11 \\
\hline LD4 & -0.61 & 0.48 & LD4 & -0.77 & 0.09 \\
\hline LMC & -0.64 & -0.75 & LMC & -0.20 & 0.91 \\
\hline $\mathrm{LmC}$ & -0.11 & 0.60 & $\mathrm{LmC}$ & -0.07 & 0.81 \\
\hline LM1 & -0.77 & 0.26 & LM1 & -0.90 & -0.20 \\
\hline LM4 & -0.93 & 0.23 & LM4 & -0.94 & -0.01 \\
\hline OW & -0.75 & -0.50 & OW & -0.62 & 0.02 \\
\hline TLA1 & -0.88 & 0.31 & TLA1 & -0.93 & -0.05 \\
\hline TLA4 & -0.90 & 0.34 & TLA4 & -0.95 & 0.09 \\
\hline WM1 & -0.79 & 0.19 & WM1 & -0.71 & 0.22 \\
\hline WM4 & -0.72 & 0.20 & WM4 & -0.72 & 0.17 \\
\hline Explained variance $(\%)$ & 57.32 & 26.82 & Explained variance (\%) & 65.48 & 14.41 \\
\hline
\end{tabular}

animals of different taxonomic groups (FELLEY, 1984; WIKRAMANAYAKE, 1990; AGUIRREL et al., 2002; TEIXEIRA; BENNEMANN, 2007; KIRCHHEIM; GOULART, 2010). However, other authors have observed low correlations between morphological traits and habitats, suggesting that this type of analysis would be more effective in comparisons of species belonging to the same family and not among those belonging to different groups (DOUGLAS; MATTHEWS, 1992). In the present study we have demonstrated the existence of consistent relationships between the morphology and habitats occupied.

The short legs (LTA1 LTA4) among species composing the Complex Substrates group are probably associated with an adaptation to traversing uneven surfaces, and entering hollows and crevices. Studies on the natural history of $P$. transversus by ABELE et al. (1986) support this idea: This typical crab of hard substrate uses cracks and crevices as refuges from both predators and waves.

The robust major cheliped of the group of Complex Substrates indicates a well-developed musculature, that could be a useful tool in breaking and opening shells of bivalves or the hard exoskeletons of crustaceans. The experiments of SMITH and PALMER (1994) support this assumption: groups of crabs Cancer productus (RANDALL, 1839) fed in the laboratory on hard prey items (shells) developed larger and more robust cheliped propodus than those fed on "soft prey". Additionally, robust chelipeds may also assist in protecting crabs against the mechanical action of waves by improving the contact area and adherence of the body to the uneven substrate. This inference is based on the study of Eriphia verrucosa (FORSKAL, 1775) by SILVA et al. (2010), who recorded individuals with stronger chelipeds in exposed biotopes of rocky shores than those found in protected areas of the same environments. These observations may explain the robust major cheliped of the crabs in the Complex Substrates of this study, which are composed of Eriphidae, Grapsidae, Menippidae, Panopeidae and Pilumnidae, found on rocky shores and in oyster lantern nets. However, the Semiterrestrial crabs that also have robust major chelipeds require a different explanation for their large cheliped, likely related to agonistic and social behavior (CRANE, 1975).

The long eyestalks of the Semiterrestrial species are related to visual activities, more important in terrestrial environments. In this habitat visual and acoustic perception are of critical importance for reproductive purpose and for avoiding predators, as well being used to recognise feeding areas near burrows by means of visual landmarks (BLISS, 1968; THIEL; BREITHAUPT, 2011).

The long LTA4 of these crabs suggests an advantage against predation, since these legs allow an increase in the range of movement which, in its turn, increases the 

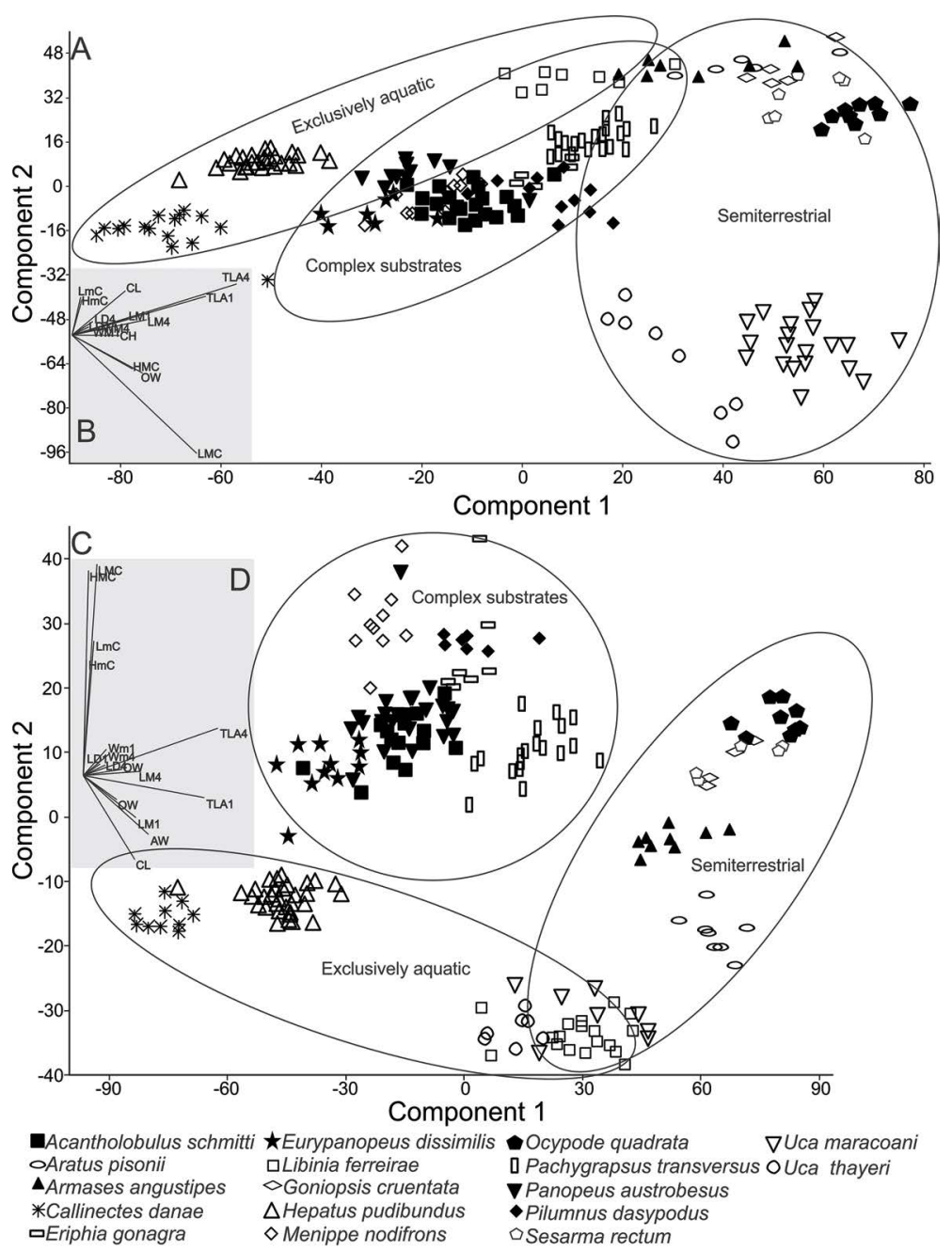

Figure 2. A: Principal Component Analysis (PCA) of brachyuran crab males. B: Biplot regarding the PCA of males. C: PCA of brachyuran crab females. D: Biplot regarding the PCA of females.

speed and endurance of the crabs, especially during intermittent locomotion (WEINSTEIN; FULL, 1998). In a study conducted on the ghost crab $O$. quadrata, WEINSTEIN and FULL (1998) observed that at an air temperature of $15^{\circ} \mathrm{C}$ and a continuous mean speed of $0.04 \mathrm{~ms}^{-1}$ for 60 seconds, crabs could travel for $60 \mathrm{me}-$ ters before becoming fatigued. On the other hand, when moving intermittently, with alternating 30 second periods of walking and resting, and an average speed of 0.08 $\mathrm{ms}^{-1}$, the crabs could travel 271 meters before becoming fatigued - about four times greater than the distance of continuous locomotion.

The short dactyls of Semiterrestrial A. pisonii, a tree climbing species, are thought to aid in rapidly traversing the rough surfaces of mangrove trunks (WARNER, 1967; FRANTINI et al., 2005).
Besides the tendency to be large, the narrow merus of P1 in the Exclusively Aquatic group indicates undeveloped muscles for body movements. Additionally, the short eyestalk of this crab group can be taken to suggest that visual perception may not be of primary importance in the water column (THIEL; BREITHAUPT, 2011).

The swimming crab $C$. danae has modified dactyls of its ambulatory legs 4 into "paddles" for swimming which allow rapid swimming (over 1 m.s.-1) and high manoeuvrability (BOOTH; MCMAHON, 1992). The short, wide merus of ambulatory legs 4 indicates developed musculature for body movements that enable the crab to swim rapidly. The dorso-ventrally flattened carapace creates less resistance during swimming, and consequently reduces the energetic costs of swimming. These features allow these crabs to be aggressive predators of benthic habitats 


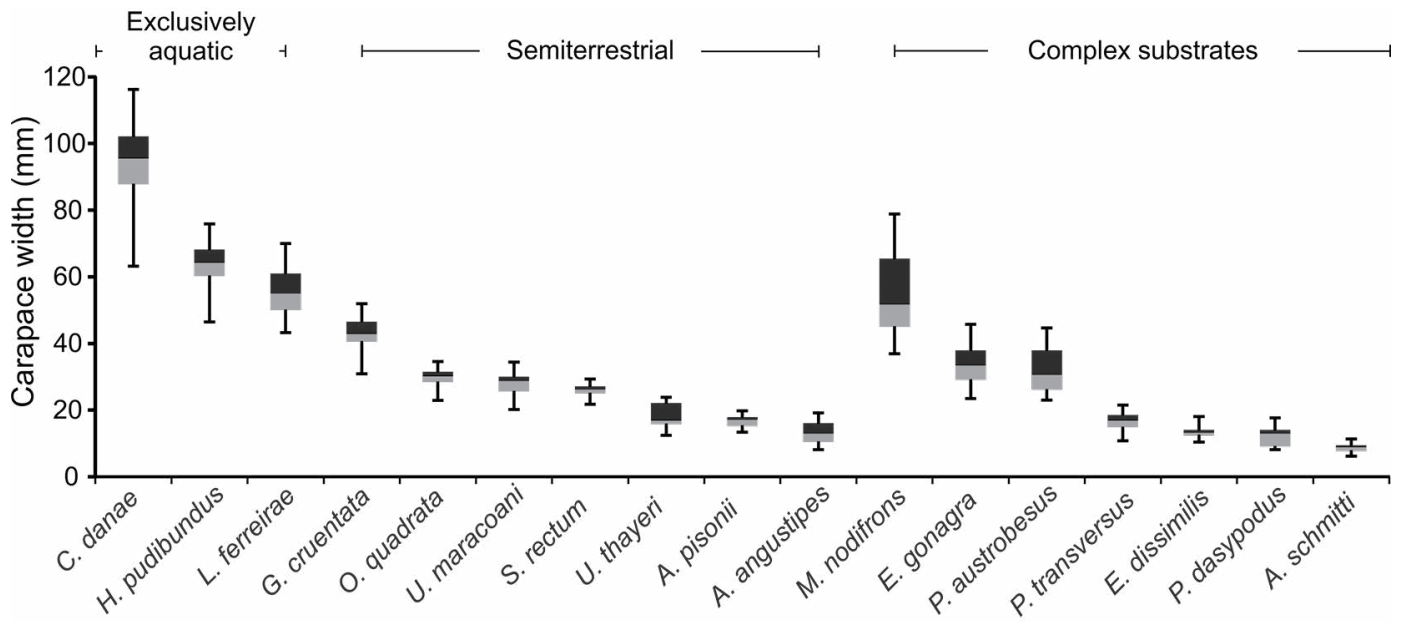

Figure 3. Mean (horizontal line), maximum/minimum values (vertical lines in each box) and CW range of 50\% of data (box) of the brachyuran crabs recorded in the three habitat types.
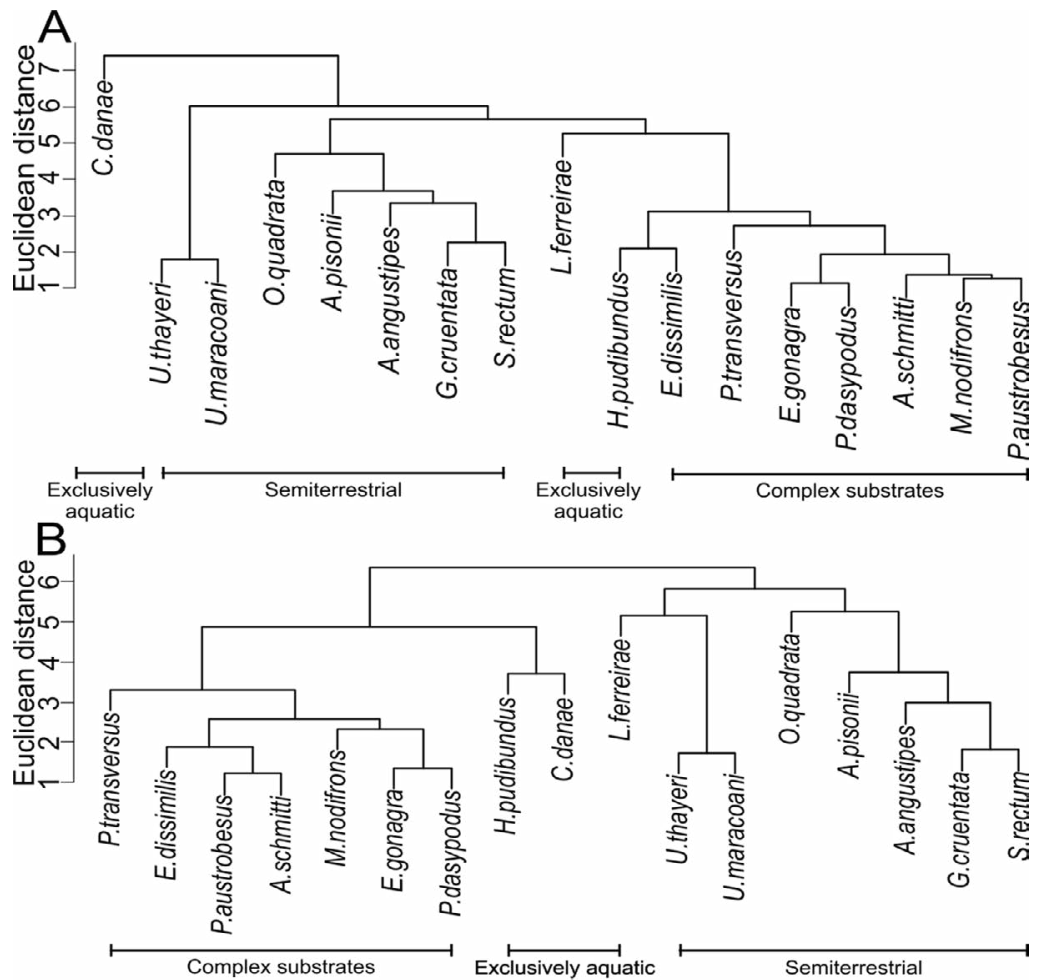

Figure 4. Grouping analysis (UPGMA) using the Euclidean distance matrix of the linear measurements of analyzed crab species.

(WRIGHT et al., 1996; MANTELATTO; FRANSOZO, 1999; MANTELATTO; CHRISTOFOLETTI, 2001; SEITZ et al., 2003).

The long, narrow merus of the ambulatory legs 1 and 4 found in L. ferreirae indicates muscles which though underdeveloped are sufficient for locomotion in aquatic environments where the species is aided by buoyancy. Due to the low visibility in this habitat, foraging is accomplished primarily using chemosensory organs, thus explaining the short eyestalks found in this crab (THIEL; BREITHAUPT, 2011).

For most crustaceans, the risk of predation diminishes with increasing body size (ORENSANZ; GALLUCI, 1988; WAHLE; STENECK, 1992; HARRISON; CRESPI, 1999). Although more susceptible to predation, small-sized 
Table 3. Statistical test of differences between three habitat groups and taxonomic level (total $n=392$ ) by two-way multivariate analysis of variance (PERMANOVA), based on 15 (male) and 16 (female) proportional linear measurements.

\begin{tabular}{|c|c|c|c|c|c|}
\hline Source & D.F & SS & MS & $\mathrm{F}$ & $p$ \\
\hline Habitat & 1 & 0.125 & 0.125 & 120.46 & $<0.001$ \\
\hline Taxonomic level (Family) & 1 & 0.073 & 0.073 & 70.69 & $<0.001$ \\
\hline Sex & 1 & 0.022 & 0.022 & 21.40 & $<0.001$ \\
\hline Effect of habitat and taxonomic level & 1 & 0.019 & 0.019 & 18.82 & $<0.001$ \\
\hline Effect of habitat and sex & 1 & 0.002 & 0.002 & 2.41 & 0.076 \\
\hline Effect of taxonomic level and sex & 1 & -0.0006 & -0.0006 & -0.60 & 1 \\
\hline Effect of habitat, taxonomic level and sex & 1 & -0.0004 & -0.0004 & -0.45 & 1 \\
\hline Residual & 384 & 0.398 & 0.001 & & \\
\hline Total & 391 & 0.64 & & & \\
\hline
\end{tabular}

crabs developed many strategies to avoid predation. Taking into account the $\mathrm{CW}$ of the crabs studied, the Complex Substrates group (rocky shores, oyster banks and fallen logs) was composed of small and medium-sized species, whereas those of the more homogeneous habitats (marine bottoms) were composed of species with an average $\mathrm{CW}$ of over $20.00 \mathrm{~mm}$. The predominance of small-sized crab species in habitats with complex substrates can be explained by the large number of small refuges in these habitats provided by the crevices, hollows and micro depressions which serve as very effective protection against their predators (HARRISON; CRESPI, 1999).

On the other hand, the size of the body of the largesized crab species can in itself lower the risk of predation. This explanation may be applied to the predominance of larger crab species in the exclusively aquatic environments of the present study, where small refuges are scarce.

The significant differences between the morphology of the males and females of different taxa and habitats reinforce the widely known sexual dimorphism of the Decapoda by means of morphometric approaches (HARTNOLL, 1974).

The presence of different crab lineages in the environments analyzed (Complex Substrates: Eriphidae, Grapsidae, Menippidae, Panopeidae and Pilumnidae; Semiterrestrial: Grapsidae, Ocypodidae and Sesarmidae; Exclusively Aquatic: Epialtidae, Aethidae and Portunidae) suggests the convergent evolution of morphological traits aimed at optimising performance in the specific habitat to which the crabs are adapted.

The environment in which an animal lives, combined with selection caused by predation, could affect its morphology, and consequently communication and reproductive pattern. The distinct morphological patterns of brachyuran crabs found for each biotope in the present study indicate that it is possible to establish typical crab morphologies for each habitat. The morphological characters that most influenced the distribution of brachyuran crab species (length and width of ambulatory legs and length and height of cheliped propodus) were, in general, related with facility of displacement within each microhabitat, as well as intraspecific communication and avoidance of predators.

\section{ACKNOWLEDGEMENTS}

We are thankful to Prof. Dr. Tânia Marcia Costa from Paulista State University, Prof. Dr. Janete Dubiaski-Silva from Pontifical Catholic University of Paraná and Prof. Dr. Marco Fábio Corrêa from Federal University of Paraná for useful comments and suggestions to this work. Dr. Tomer Czaczkes from University of Regensburg provided useful comments, suggestions and English revision and Dr. Odete Lopez Lopes from Museum of Natural History of Capão da Imbuia provided the deposited crab specimens. Thanks are also due to Brazilian Council for Scientific and Technological Development-CNPq for the master scholarship to the first author. All biological samples collecting of the present study complies with the current laws of Paraná State and Brazilian Federal Government, and it was conducted with the permission of the "Brazilian Institute of Environment and Renewable Natural Resources (IBAMA) of Paraná State" (Authorization \#23482-1-DIFAP/IBAMA, 30/03/2010). This is Contribution \#1895 of Zoology Department, Federal University of Paraná.

\section{REFERENCES}

ABELE, L. G.; CAMPANELFLA, P. J.; SALMON, M. Natural history and social organization of the semiterrestrial grapsid crab Pachygrapsus transversus (Gibbes). J. Exp. Mar. Biol. Ecol., v. 104, n. 1/3, p. 153-170, 1986. 
AGUIRREL, L. F.; HERREL, A.; DAMME, R.; MATTHYSEN, E. Ecomorphological analysis of trophic niche partitioning in a tropical savannah bat community. Proc. Biol. Sci., v. 269, n. 1497, p. 1271-1278, 2002.

BETZ, O. Life forms and hunting behaviour of some Central European Stenus species (Coleoptera, Staphylinidae). Appl. Soil. Ecol., v. 9, n. 1, p. 69-74, 1998.

BLISS, D. E. Transition from water to land in decapod crustaceans. Am. Zool., v. 8, p. 355-398, 1968.

BOOTH, C. E.; MCMAHON, B. R. Aerobic capacity of the blue crab, Callinectes sapidus. Physiol. Zool., v. 65, n. 6, p. 10741091, 1992.

CARVALHO, A. L. G.; ARAÚJO, A. F. B. Ecomorphometric structure of Restinga da Marambaia lizard community, Rio de Janeiro, southeastern Brazil. Rev. Bras. Zool., v. 24, n. 3, p. 786-792, 2007.

CRANE, J. Fiddler crabs of the world: Ocypodidae: genus Uca. New Jersey: Princeton University Press, 1975. 736 p.

DARWIN, C. The Origin of Species by Means of Natural Selection or the Preservation of Favoured Races in the Struggle for Life. London: John Murray, 1859.

DE GRAVE, S.; PENTCHEFF, N. D.; AHYONG, S. T.; CHAN, T. Y.; CRANDALL, K. A.; DWORSCHAK, P. C.; FELDER, D. L.; FELDMANN, R. M.; FRANSEN, C. H. J. M.; GOULDING, L. Y. D.; LEMAITRE, R.; LOW, M. E. Y.; MARTIN, J. W.; NG, P. K. L.; SCHWEITZER, C. E.; TAN, S. H.; TSHUDY, D.; WETZER, R. A classification of living and fossil genera of decapod crustaceans. Raffles Bull. Zool., v. 21, p. 1-109, 2009.

DOUGLAS, M. E.; MATTHEWS, W. J. Does morphology predict ecology? Hypothesis testing within a freshwater stream fish assemblage. Oikos, v. 65, p. 213-224, 1992.

FELLEY, J. D. Multivariate identification of morphological - environmental relationships within the Cyprinidae (Pisces). Copeia, v. 2, p. 442-455, 1984.

FRANTINI, S.; VANINI, M.; CANNICCI, S.; SCHUBART, C. D. Tree-climbing mangrove crabs: a case of convergent evolution. Evol. Ecol. Res., v. 7, n. 2, p. 219-233, 2005.

GATZ, A. J. Community organization in fishes as indicated by morphological features. Ecology, v. 60, p. 711-718, 1979.

GOMES, L. N.; PINHEIRO JÚNIOR, J. R.; PIORSKI, N. M. Aspectos ecomorfológicos da comunidade de peixes do estuário do Rio Anil, Ilha de São Luíz - MA. Bol. Lab. Hidrobiol., v. 16, n. 1, p. 29-36, 2003

HARRISON, M. F.; CRESPI, B. J. A Phylogenetic Test of Ecomorphological Adaptation in Cancer Crabs. Evolution, v. 53, n. 3, p. 961-965, 1999.

HARTNOLL, R. G. Variation in growth pattern between some secondary sexual characters in crabs (Decapoda Brachyura). Crustaceanas, v. 27, n. 2, p. 131-136, 1974.

HINES, A. H. Fecundity and reproductive output in nine species of Cancer crabs (Crustacea, Brachyura, Cancridae). Can. J. Fish. Aquat. Sci., v. 48, p. 267-275, 1991.

IRSCHICK, D. J.; VITT, L. J.; ZANI, P. A.; LOSOS, J. B. A comparison of evolutionary radiations in mainland and Caribbean Anolis lizards. Ecology, v. 78, n. 7, p. 2191-2203, 1997.

KARR, J. R.; JAMES, F. C. Eco-morphological configurations and convergent evolution in species and communities. In: CODY, M. L.; DIAMOND, J. M. (Eds.). Ecology and evolution of communities. Boston: Harvard University Press, 1975. p. 191-258.
KEAST, A. The piscivore feeding guild of fishes in small freshwater ecosystems. Environ. Biol. Fish, v. 12, n. 2, p. 119-129, 1985.

KESLER, D. H.; BAILEY, R. C. Density and ecomorphology of a fresh water mussel (Elliptio complanata, Bivalvia: Unionidae) in a Rhode Island lake. J. N. Am. Benthol. Soc., v. 12, n. 3, p. 259-264, 1993.

KIRCHHEIM, P. D.; GOULART, E. Ecomorfologia de predação e antipredação em Siluriformes (Osteichthyes). Oecol. Aust., v. 14, n. 2, p. 550-568, 2010.

LABROPOULOU, M.; ELEFTHERIOU, A. The foraging ecology of two pairs of congeneric demersal fish species: importance of morphological characteristics in prey selection. J. Fish. Biol., v. 50, p. 324-340, 1997.

LINDSEY, C. C. Form, function, and locomotory habits in fish. In: HOAR, W. S.; RANDALL, D. J. (Eds.). Fish physiology Vol. VII Locomotion. New York: Academic Press, 1978. p. 1-100.

MANTELATTO, F. L. M.; FRANSOZO, A. Reproductive biology and moulting cycle of the crab Callinectes ornatus (Decapoda, Portunidae) from the Ubatuba region, São Paulo, Brazil. Crustaceana, v. 72, n. 1, p. 63-73, 1999.

MANTELATTO, F. L. M.; CHRISTOFOLETTI, R. A. Natural feeding activity of the crab Callinectes ornatus (Portunidae) in Ubatuba Bay (São Paulo, Brazil): Influence of season, sex, size and the molt stage. Mar. Biol., v. 138, n. 3, p. 585-594, 2001.

MAROCHI, M. Z.; MASUNARI, S. Os caranguejos Eriphiidae, Menippidae, Panopeidae e Pilumnidae (Crustacea Brachyura) de águas rasas do litoral do Paraná, com chave pictórica de identificação para as espécies. Biota Neotrop., v. 11, n. 3, p. $1-13,2011$.

MASUNARI, S. Organismos do fital Amphiroa beauvoisii Lamouroux, 1816 (Rhodophyta: Corallinaceae) I. Autoecologia. Bol. Zool. Univ. São Paulo, v. 7, n. 1, p. 57-148, 1982.

MASUNARI, S. Distribuição e abundância dos caranguejos $U c a$ Leach (Crustacea, Decapoda, Ocypodidae) na Baía de Guaratuba, Paraná Brasil. Rev. Bras. Zool., v. 23, n. 4, p. 901-914, 2006.MASUNARI, S.; DUBIASKI-SILVA, J. Crustacea Decapoda da praia rochosa da Ilha do Farol, Matinhos, Paraná. I. Distribuição espacial de densidade das populações. Rev. Bras. Zool., v. 15, n. 3, p. 643-664, 1998.

MELO, G. A. S. Manual de identificação dos Brachyura (caranguejos e siris) do litoral brasileiro. São Paulo: Plêiade/ FAPESP, 1996. 604 p.

NG, P. K. L.; GUINOT, D.; DAVIE, P. J. F. Systema Brachyurorum: Part I. An annotated checklist of extant brachyuran crabs of the world. Raffles Bull. Zool., v. 17, p. 1-286, 2008.

NORTON, S. F.; LUCZKOVICH, J. J.; MOTTA, P. J. The role of ecomorphological studies in the comparative biology of fishes. Environ. Biol. Fishes, v. 44, n. 1, p. 287-304, 1995.

OKSANEN, J.; BLANCHET, F. G.; KINDT, R.; LEGENDRE, P.; MINCHIN, P. R.; O’HARA, R. B.; SIMPSON, G. L.; SOLYMOS, P.; STEVENS, M. H. H.; WAGNER, H, 2012. Community Ecology Package, version 2.0-4. Available: <URL: http://CRAN.R-project.org/package=vegan $>$ Accessed: January 2015

ORENSANZ, J. M.; GALLUCCI, V. E. Comparative study of postlarval life-history schedules in four sympatric species of Cancer (Decapoda: Brachyura: Cancridae). J. Crust. Biol., v. 8, n. 2, p. 187-220, 1988.

PIELOU, E. C. The interpretation of ecological data. New York: John Wiley \& Sons, 1984. 263 p. 
PIORSKI, N. M.; ALVES, J. R. L.; MACHADO, M. R. B; CORREIA, M. M. F. Alimentação e ecomorfometria de duas espécies de piranhas (Characiformes: Characidae) do Lago de Viana, Estado do Maranhão, Brasil. Acta Amaz., v. 35, n. 1, p. 63-70, 2005.

PIORSKI, N. M.; DOURADO, E. C. S.; NUNES, J. L. S. Análise ecomorfológica de três espécies de peixes do parque estadual marinho do Parcel de Manuel Luiz, nordeste do Brasil. Bol. Lab. Hidrobiol, v. 20, p. 69-76, 2007.

R Development Core Team. R: A language and environment for statistical computing. R Foundation for Statistical Computing, Vienna, Austria. 2011. ISBN 3-900051-07-0. Available: < URL: http://www> Rproject.org/> Accessed: January 2015.

RIBAS, S. C.; VELLOSO, A. L. R.; TEIXEIRA-FILHO, P.; ROCHA-BARBOSA, O.; EVANGELISTA, H.; SANTOS, E. A. Structure of claws and toes of two tropidurid lizard species of Restinga from Southeastern Brazil: adaptations to the vertical use of the habitat. Rev. Chil. Hist. Nat., v. 77, n. 4, p. 599-606, 2004.

SEITZ, R. D.; LIPCIUS, R. N.; STOCKHAUSEN, W. T.; DELANO, K. A.; SEEBO, M. S.; GERDES, P. D. Potential bottom-up control of blue crab distribution at various spatial scales. Bull. Mar. Sci., v. 72, n. 2, p. 471-490, 2003.

SILVA, A. C.; SILVA, I. C.; HAWKINS, S. J.; BOAVENTURA, D. M.; THOMPSON, R. C. Cheliped morphological variation of the intertidal crab Eriphia verrucosa across shores of differing exposure to wave action. J. Exp. Mar. Biol. Ecol., v. 391, n. 1/2, p. 84-91, 2010

SOKAL, R. R.; ROHLF, F. J. The comparison of dendrograms by objective methods. Taxon, v. 11, p. 33-40, 1962.

SMITH, L. D.; PALMER, A. R. Effects of manipulated diet on size and performance of brachyuran crab claws. Science, v. 264, n. 5159, p. 710-712, 1994.

STREELMAN, J. T.; ALFARO, M.; WESTNEAT, M. W.; BELLWOOD, D. R.; KARL, S. A. Evolutionary history of the parrotfishes: biogeography, ecomorphology, and comparative diversity. Evolution, v. 56, n. 5, p. 961-971, 2002.
TEIXEIRA, I.; BENNEMANN, S. T. Ecomorfologia refletindo a dieta dos peixes em um reservatório no sul do Brasil. Biota Neotrop., v. 7, n. 2, p. 67-76, 2007.

THIEL, M; BREITHAUPT, T. Chemical communication in crustaceans: research challenges for the twenty-first century. In: BREITHAUPT, T.; THIEL, M. (Eds.). Chemical communication in crustaceans. London: Springer, 2011. 565 p.

TRONTELJ, P.; BLEJEC, A.; FIŠER, C. Ecomorphological convergence of cave communities. Evolution, v. 66, n. 12, p. 3852-3865, 2012.

VAN DER KLAAUW, C. J. Ecological Studies and reviews. IV. Ecological morphology. Leiden: E. J. Brill, 1948. p. 27-111.

VANHONI, F.; MENDONÇA, F. O clima do litoral do estado do Paraná. Rev. Bras. Climat., v. 3, p. 49-63, 2008.

WARNER, G. F. The life history of mangrove tree crab, Aratus pisoni. J. Zool., v. 153, n. 3, p. 321-335, 1967.

WAHLE, R. A.; STENECK, R. S. Habitat restrictions in early benthic life: experiments on habitat selection and in situ predation with the American lobster. J. Exp. Mar. Biol. Ecol., v. 157, n. 1, p. 91-114, 1992.

WEINSTEIN, R. B.; FULL, R. J. Performance limits of low-temperature, continuous locomotion are exceeded when locomotion is intermittent in the ghost crab. Physiol. Zool., v. 71, n. 3, p. 274-284, 1998

WIKRAMANAYAKE, E. D. Ecomorphology and biogeography of a tropical stream fish assemblage: evolution of assemblage structure. Ecology, v. 71, n. 5, p. 1756-1764, 1990.

WINEMILLER, K. O. Ecomorphological diversification in lowland freshwater fish assemblages from five biotic regions. Ecol. Monogr., v. 61, n. 4, p. 343-365, 1991.

WRIGHT, R. A.; CROWDER, L. B.; MARTIN, T. H. Selective predation by blue crabs on the gastropod, Bittium varium: confirmation from opercula found in the sediments. Estuaries, v. 19, n. 1, p. 75-81, 1996.

YAMADA, S. B.; BOULDING, E. G. Claw morphology, prey size selection and foraging efficiency in generalist and specialist shell-breaking crabs. J. Exp. Mar. Biol. Ecol., v. 220, n. 2, p. 191-211, 1998. 
